\title{
Deminutiivsete noomenite funktsionaalsusest vene ja eesti keeles mõningate Tšehhovi jutustuste ning nende tõlgete näitel
}

\begin{abstract}
SIRJE KUPP-SAZONOV
Tartu Ülikool

Ülevaade. Uurimus keskendub deminutiividele eesti ja vene keeles. Venekeelsete lähtetekstide ja nende eestikeelsete tõlgete analüüsist nähtub, et deminutiividega saab väljendada mitmeid erinevaid tähendusi (objektide mõõtmeid, elusolendite väiksust, hellitavat/ halvustavat suhtumist jne). Kõrvutamiseks on valitud ühest küljest deminutiivide moodustusviiside ja kasutusvõimaluste poolest rikas vene keel ning teisest küljest eesti keel, kus nende vormide tuletus- ja esinemissagedus on silmnähtavalt tagasihoidlikumad. Sellest hoolimata näib, et isegi kui eesti keeles on vähem tavaks deminutiive tuletada ja kasutada, siis tähenduste spekter on vene keele omaga suuresti kattuv. Lähtekeele lausete kõrvutamisel sihtkeele vastetega ilmneb, et harvad pole juhud, mil tõlkijad on üritanud deminutiivi puudumist teiste vahenditega kompenseerida, mis tõestab, et ka tõlkes on peetud oluliseks originaalteksti deminutiivi funktsiooni võimaluse piires säilitada.
\end{abstract}

Võtmesõnad: kontrastiivgrammatika; deminutiivid; tõlkimine; vene keel; eesti keel 


\section{Uurimuse eesmärgid ja teoreetiline raamistik}

Artikli eesmärkideks on 1) analüüsida, millised on deminutiivsete noomenite funktsioonid kahekümnes Anton Tšehhovi jutustuses; 2) selgitada välja, kas need funktsioonid säilivad ka eestikeelsetes tõlgetes ning 3) tuvastada, kas ja milliste vahenditega tõlkijad deminutiivide puudumist eestikeelses tekstis kompenseerivad. Artikliga soovitakse anda panus eelkõige deminutiividega seotud tõlkeprobleemide uurimisse.

Tšehhovi keelt ja kirjutamisstiili on analüüsitud palju (GalkinaFedoruk 1960; Azarova 2011; Koževnikova 2011; Gadžijeva 2014 jt), muuhulgas on vaadeldud ka deminutiivide rolli tema teostes. On leitud, et ta kasutab deminutiive näitamaks oma (iroonilist, koomilist, sarkastilist jm) suhtumist tegelastesse ja teoses kirjeldatavasse olukorda (Vaffa \& Kovaljov 2013: 116). Tšehhovi tekstides on erilisel kohal okasionaaldeminutiivid, st autori enda "leiutatud" vormid, mida vene keeles muidu ei esine, kuigi grammatilisi takistusi nende vormide moodustamiseks ei ole (Vaffa 2013: 7-8).

Artikli teoreetilise raamistiku moodustavad erinevate eesti ja vene keeleteadlaste deminutiividele pühendatud käsitlused. Uurimuse seisukohast on olulised järgmised teemad: kuidas deminutiive defineeritakse, neid tuletatakse ja millised on nende (peamised) funktsioonid. Lisaks on käesolevas uurimuses tuginetud ka mõningatele teiste keelte deminutiive kirjeldavatele töödele, nt Wierzbicka 1984; Dressler \& Barbaresi 1994; Menkova 2010; Lockyer 2012; Bagasheva-Koleva 2016 jt. Deminutiivide klassifitseerimise kohta vt Tšervenkova 1965; Jurafsky 1996; Schneider 2003; Bosanac jt 2009 jt. Ülevaatliku kokkuvõtte deminutiivide uurimise ajaloost erinevates keeltes saab Ella ja Yuliya Mintsyse artiklist (2015: 29-30). 
DEMINUTIIVSETE NOOMENITE FUnKtSIONAALSUSEST ...

\subsection{Deminutiivid vene keeleteaduses}

Vene keeleteadlaste töödes on deminutiividele mõnevõrra rohkem tähelepanu pööratud. Terminile deminutiivsufiksid eelistatakse oskussõnu vähendussufiksid (vn уменьшительные суффиксы), subjektiivsed hinnangulised sufiksid (субъективно-оценочные суффиксы) või vähendavad hellitavad sufiksid (уменьшительно-ласкательные суфбиксы) (Fufajeva 2017: 19). Väidetavalt oli Mihhail Lomonossov esimene, kes juba 18. sajandil kirjeldas esimeses vene keele akadeemilises grammatikas deminutiivsufiksitega noomeneid ja adjektiive. Edasi pälvisid deminutiivid selliste teadlaste nagu Anton Barsovi, Fjodor Buslajevi, Aleksandr Vostokovi, Aleksei Šahmatovi ja Viktor Vinogradovi tähelepanu, nemad keskendusid eelkõige subjektiivset hinnangulisust väljendavatele morfeemidele ning nende abil moodustatud sõnade semantikale (Fufajeva 2017: 25). 20. saj keskpaigas hakati arutama, kas deminutiive tuleks vaadelda kui iseseisvaid lekseeme või on need sõnade grammatilised vormid, see küsimus ja deminutiivide liigitus põhjustavad vaidlusi siiani (Šeidajeva 1998: 3). 20. saj lõpu ja 21. saj töödes on deminutiive analüüsitud ka suulises kõnes: lastekeeles, linnaelanike keeles ja dialektides, samuti soouuringutes. Üksikasjalikuma ülevaate deminutiivide uurimise ajaloost vene keeleteaduses annab Fufajeva (2017: 19-28).

Kuna selle artikli seisukohast on olulised eelkõige deminutiivide funktsionaalsust analüüsivad käsitlused, siis väärivad esile tõstmist järgmised teosed: Bratus (1969), "Vene keele akadeemiline grammatika” (VKAG I 1980), Rezanova (1996), Spiridonova (1999), Protassova (2001), Kuzmenkova (2007) jt.

Protassova on täheldanud, et deminutiivsufksite kasutamine vene keeles on üsna keeruline nähtus. Ühest küljest annab deminutiivide oskuslik tuletamine tunnistust kõneleja heast keeletajust, keele suurepärasest valdamisest. Teisest küljest aga on deminutiivid nii suure ekspressiivsuse laenguga elemendid, et võivad hõlpsasti osutuda mitterelevantseks, kõlada võltsilt ning näidata kõnelejat hoopiski halvas valguses, kui neid ei kasutata õiges kohas ja õigel ajal (Protassova 2001: 72). 
Sageli näitab deminutiivsufiksi kasutamine kõneleja isiklikku suhtumist ning kui soovitakse väljenduda neutraalselt, tuleks eelistada adjektiivist ja noomenist koosnevaid sõnapaare, näiteks majakese asemel öelda väike maja jne (Protassova 2001: 75).

Võrreldes paljude teiste keeltega, sh ka slaavi keeltega, paistab vene keel silma regulaarselt esinevate deminutiivsufiksite rohkusega, nt

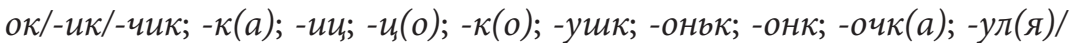
$-y н(я) /-y c(я) /-y щ(a) ;-$-онок. Teatud sufikseid saab kasutada vaid kindlast

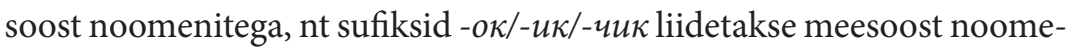
nite tüvele (городок - linnake, ключик - võtmeke jms), sufiksiga -к(a) saab deminutiive tuletada naissoost noomenitest (деревенька 'külake', старушка 'eideke' jms). Mõningad tuletusliited on n-ö spetsialiseerunud vaid hellitava või halvustava tähenduse väljendamiseks. Vene keeles ei piirdu deminutiivide tuletusvõimalused vaid noomeni ja adjektiiviga, lisaks neile saab deminutiive moodustada ka adverbidest (VKAG I 1980: 401-402) ja isegi interjektsioonidest (VKAG I 1980: 732-734).

Esineb nn sufikstermineid, st deminutiiv tähistab mingit oskuskeele sõna, nt ametlikud sugulusterminid on тётка (1. tähendus 'tädi, ema või isa õde', samuti 'onu naine') ja бабка (1. tähendus 'vanaema') (Protassova 2001: 75). Mõnikord deminutiivsuse tähendus väheneb või see kaob sootuks, sellisel juhul deminutiivid leksikaliseeruvad (Bosanac jt 2009: 22). Neid nimetatakse kivistunud deminutiivideks (ingl frozen diminutives; Böhmerová 2011: 4), kuna kuigi need säilitavad oma vormi, toimub nihe nende semantikas. Selliste deminutiivide tähendus võib sarnaneda alussõna semantikaga, aga võib ka sellest erineda, nt полотно 'lõuend' > полотенце 'käterätik'. Leksikaliseerumine on kas täielik või osaline (Tšervenkova 1961: 50) ning paljudest sellistest deminutiividest on saanud (tehnilised) terminid (Spiridonova 1999: 9).

Eraldi rühma moodustavad pärisnimedest tuletatud deminutiivid, seda teemat on põgusalt puudutatud ühes eestlaste ja venelaste suhtluskäitumist analüüsivas artiklis (Pajusalu jt 2010: 218). Üksikasjaliku ülevaate erinevate keelte isikunimedest moodustatavatest deminutiividest on kirjutanud Anna Wierzbicka (1992). 
Näib, et nüüdseks on välja kujunenud deminutiivide funktsioonide traditsiooniline liigitus:

1) suuruse ja hinnagu väljendamine (vn размерно-оценочное значение), mis jaguneb omakorda:

a) vähendav-hellitav tähendus (уменьшительно-ласкательное), nt зверюшка 'väike armas metsloom';

b) vähendav-halvustav tähendus (уменьшительно-уничижительное), nt избёнка 'väike kehv tare';

2) ainult hinnangu väljendamine (чисто оценочное значение), mis jaguneb:

a) ainult hellitav tähendus (чисто ласкательное), nt доченка 'tütreke';

b) ainult halvustav tähendus (чисто уничижительное), nt тюдишки 'tühised, tähtsusetud inimesed';

3) (ainult) suuruse väljendamine (размерное значение), nt печка 'väike ahi'.

4) viisakuse, lugupidamise väljendamine (значение вежливости) - viisakust tuleb antud juhul mõista mõnevõrra tinglikult, selle tähenduse alla liigitub ka familiaarsus (VKAG I 1980: 208-218). On täheldatud, et viisakuse funktsiooni täidavad deminutiivid eelkõige palve esitamisel või vabandamisel (Protassova 2001: 86). Väidetakse ka, et seda funktsiooni väljendasid erinevatest toiduainete nimetustest tuletatud deminutiivid näiteks Nõukogude Liidus defitsiidi ajastul, mil need olid omamoodi etiketinormiks (Zemskaja 1981: 13), nt Пожалуйста, двести грамм колбаски 'Palun kakssada grammi vorstikest'. Selliste deminutiivide kasutamist on uuritud ostusituatsioonis ja jõutud järeldusele, et vene keeles esinevad deminutiivid eelkõige ostjate keeles, samal ajal, kui nt tšehhi kultuuriruumis kasutavad deminutiive suhtluses just müüjad (Kozlovskaja 1992: 55). Kindlasti ei esine deminutiivid vaid pelgalt poe või turu ostuolukorras, vaid ka teistel klienditeeninduse juhtudel (ettekandja, juuksuri jm teenindava personali vestluses kliendiga). 
Suuruse tähendust võib liigitada veel järgnevalt (Rezanova 1996: 169): a) parameetritelt väike, nt домик 'majake'; b) väiksema intensiivsusega, nt ветерок 'tuuleke'; c) väiksema tähtsusega, nt статейка 'artiklike'; d) mingisuguste omaduste poolest normist kõrvalekalduv, nt супчик 'supike'. Viimane funktsioon jäb ebaselgeks, kuna autor ei ole seda ideed pikemalt lahti seletanud, vaid on toonud lihtsalt kaks näidet супчик (cyn 'supp') ja горошек (горох 'hernes'). Vene keele korpuse ilukirjandustekstide allkorpuse näidetes esineb sõna супчuк nii positiivse kui ka negatiivse konnotatsiooniga, sõltuvalt lause üldisest kontekstist. Seega pole päris selge, milliste omaduste poolest see supp normist kõrvale kaldub. Siinkirjutajale näib, et pigem paigutub cynчuк koos teiste erinevate toiduainete ning roogadega hoopis viisakuse ja aupakliku suhtumise funktsiooni alla.

\subsection{Deminutiivid eesti keeleteaduses}

Eesti keele deminutiivide uurimise alguseks võib tõenäoliselt pidada Julius Mägiste käsitlusi (Mägiste 1928, 1929), ehkki juba Jakob Hurda 1886. aasta väitekirjas on mainitud deminutiivseid noomeneid (Kasik 2009: 33). 2006. aastal kirjutasid Petar Kehayov ja Rogier Blokland, et kuna eesti keele sõnamoodustuskäsitlustes on olnud domineerivaks vormikeskne lähenemine, kus vaadeldakse eelkõige moodustuselemendi funktsioone, siis "ei ole seni ühtegi eriuurimust eesti keele deminutiivituletuse kohta, see-eest võib leida palju uurimusi selliste sufiksite kohta, mis muu kõrval väljendavad ka deminutiivsust" (Kehayov \& Blokland 2006: 88). Siiski on deminutiivid pälvinud mitmete keeleuurijate tähelepanu, vt sõnamoodustusele (Kasik 2009, 2015; Vare 1981, 1994), hoidja- ja lastekeelele (Orusalu 1996; Õim 2003; Argus 2008a) ning noorte slängile (Toomejõe 2008) pühendatud käsitlusi.

Erialakirjanduses ja sõnaraamatutes võib leida mitmeid definitsioone. Deminutiiv(id) on "vähendava, meelitava, hellitleva tähendusega sõna" (EKK 2007: 622); "enamasti nimisõnad, mis tähistavad mõõtmetelt 
väikseid olendeid või esemeid, harva ka omadussõnad” (Õim 2003: 38); "vähendava, meelitava, hellitava (vahel ka halvustava) tähendusega tuletis, vähendussõna” (EKSS 2009); need ei väljenda vaid mõõtmelist väiksust, vaid sageli ka hellitlevat või pilavat suhtumist kõneobjekti (EKG 1995: 501) jne. Ene Vainik liigitab deminutiivid keelevahendite hulka, mis "sisaldavad autori emotsionaalset laetust ja viiteid tema subjektiivsetele tajudele ja kujutlustele" (Vainik 2012: 8). Eraldi rühma moodustavad sufiksterminid (Vare 1981: 58-59) - kene-liitega sõnad, kus sufiksil on mõistet eristav funktsioon (st alussõna ja tuletis tähistavad erinevaid mõisteid), nt vatsakene, lihakene jm.

Lisamärkusena olgu öeldud, et deminutiivsust võivad eesti keeles väljendada ka adjektiivid (EKK 2007: 623; Kasik 2015: 342-343) ja verbid (Kehayov \& Blokland 2006: 89).

Üldiselt on deminutiividel kolm peamist tähendust: 1) füüsiline väiksus - eelkõige elutud objektid (Kasik 2004: 138-139); 2) hellitav suhtumine; 3) halvustav suhtumine.

Võimalikud on nende tähenduste omavahelised kombinatsioonid, nt väiksus + hellitav suhtumine: koerake - собачкa. Lähtudes artikli autori isiklikust kogemusest, saab väita, et vene keeles võib sõna собачкa viidata ka suurt kasvu koerale, kui näiteks ema räägib loomast väikese lapsega. Eesti keeles ei kasutaks ema sellisel juhul tõenäoliselt sõna koerake, vaid eelistaks pigem variante kutsu või kutsa, kuna neil puuduvad viited looma suurusele.

Samuti esineb kombinatsiooni füüsiline väiksus + halvustav suhtumine, nt Tšehhovi jutustuses "Perpetum mobile" viitab üks tegelane oma lühikest kasvu vanamehest naabrile sõnadega дрянной человечишка räbal mehike. Lisaks mehikesele on Reet Kasik eraldi välja toonud veel sellised negatiivset väärtust väljendavad deminutiivid nagu vennike ja võsuke (Kasik 2015: 241), millega tõenäoliselt võib lisaks halvustavale suhtumisele viidata ka kellegi väikesele kasvule.

Kontekstita tähistavad deminutiivid eelkõige tavapärasest väiksemat või hellust tekitavat midagi/kedagi ning negatiivne tähendus tekib alles vastavas konsituatsioonis (Kerge 1991: 27). Seega võib üks ja sama sõna 
erinevas olukorras väljendada ka täiesti vastupidiseid hinnanguid, vt näited (1b) ja (2b).

(1a) Здесь, в городке, он по протекции получил место учителя в уездном училище (PN)

(1b) Siinses linnakeses sai ta eestkostmise kaudu kreiskoolis õpetaja koha $(\mathrm{PN})$

(2a) [---] в этом маленьком, грязном городишке

(2b) [---] selles väikeses räpases linnakeses

Vene keele городок 'väike linn' (viitab linna suurusele, aga võib näidata ka hellitavat suhtumist sellesse) ning городишко 'väike linn halvustavalt' väljendavad selgelt kõneleja arvamust konkreetsest linnast, adjektiiv грязный 'räpane' vaid rõhutab seda veelgi. Samal ajal on eesti keeles adjektiivi räpane kasutamine hädavajalik kõneleja negatiivse suhtumise näitamiseks, ilma selleta tähendaks linnake lihtsalt väikest linna.

Põhimõtteliselt saab negatiivset hinnangut väljendada ka positiivse konnotatsiooniga deminutiiviga, nt sõna sõbrake hoiatuse või ähvarduse kontekstis: Ära, sa, sõbrake, aja mulle siin kärbseid pähe! Iroonilist ja negatiivset suhtumist saab väljendada, viidates sõnaga isake nt Nõukogude Liidu kunagistele liidritele. Võimalik on ka vastupidine olukord, nt nurjatu võib esineda kontekstis, kus kõneleja pöördub kellegi poole hoopis õrnusega: Ah sina, nurjatu, petsid meid kõiki, kavalpea!

Küsimusele, milliseid sõnu eesti keeles tuleks deminutiivideks lugeda, ei ole lihtne vastata. Tuletistega -ke, -kene moodustatud sõnadega on asi lihtne, kui otsida EKSS-i veebiversioonist sõnu tähisega dem e deminutiiv, siis kõik kuvatavad kirjed on moodustatud nende tuletiste abil. Sõnad poisu, kutsu, notsu jms on märgendiga lastekeelne ja mitte deminutiiv, kuigi erialakirjanduses on $u$-tuletis toodud välja kui üks deminutiivi moodustusvahendeid (vt Kasik 2015: 241; Argus 2008b: 19). Keerulisemaks läheb olukord siis, kui tõstatada küsimus, kas suurusele viitavate, mentaalset hinnangut andvate ja väärtustava funktsiooniga (Kasik 2015: 241) laiendosadega väike-, pisi- (väikeametnik, pisipoiss) või hinnangulise tähendusega liitsõnad (vennaraas, autoloks) tuleks liigitada deminutiivide alla või mitte. Ühest küljest 
DEMINUTIIVSETE NOOMENITE FUNKTSIONAALSUSEST ...

näib, et selliste liitsõnade funktsioonid kattuvad paljuski deminutiivtuletistega moodustatud lekseemide omadega, kuid samas puudub neil konkreetne grammatiline tunnus, mis lubaks neid liigitada n-ö klassikaliste sufiksaalsel teel moodustatud deminutiivide hulka. Näiteks autoloksu juures on EKSS-is kirjas, et tegu on halvustava sõnaga vana ja viletsa auto kohta ning grammatilise info järgi ei ole see deminutiiv. Kehayovi ja Bloklandi (2006: 100) mittesufiksaalsele deminutiivituletusele pühendatud artiklis on deminutiivse sõna näitena toodud tita, mis EKSS-i kohaselt on sõna titt kõnekeelne vorm, millest deminutiiv on omakorda titake.

Käesoleva uurimuse sisukohast ei ole oluline range piiri tõmbamine deminutiivtuletistega moodustatud vormide ja deminutiivseid funktsioone täitvate keelendite vahele, kuna analüüsi rõhk on originaalteksti deminutiivi funktsiooni tõlkes säilimise/mittesäilimise tuvastamisel ning võimalike kompenseerivate vahendite väljatoomisel. Seega kui tõlkija on vastena kasutanud deminutiivi või selle funktsiooni täitvat keelendit, siis on need juhtumid analüüsi seisukohast võrdväärsed.

Noomenite puhul saab eesti keeles deminutiive tuletada ja/või nende funktsioone väljendada järgmistel viisidel.

1. Noomeni genitiivitüvele liituvate $\boldsymbol{k e}$ - või $\boldsymbol{k e n e}$-tuletistega, nt lapseke(ne), tuuleke jne. Tegu on produktiivse tuletustüübiga ning moodustamispiirangud on seotud alussõna tähendusega (Kasik 2015: 251). Abstraktse tähendusega noomenitest tuletatakse deminutiive harvemini kui konkreetse tähendusega noomenitest (Kasik 2015: 240). Mõnest sõnast saab moodustada kaks deminutiivi - üks väljendab hellitavat ning teine halvustavat suhtumist: mees - meheke ja mehike; vend vennake ja vennike. Deminutiive saab moodustada ka isikunimedest, nt Liinake(ne). Ühel juhul tähistab ke-tuletisega moodustatud deminutiiv isiku sugu: temake (Kupp-Sazonov 2013: 108; vene keeles deminutiivide abil soo määratlemise kohta vt Menkova 2014).

2. u-tuletisega, nt kiisu, ninnu jne. Need on omased sageli hoidja- ja lastekeelele. Deminutiivtuletust on peetud lapse jaoks oluliseks grammatika harjutamise vahendiks, nt $u$-sufiksiga deminutiivide tuletamine 
aitab omandada vormimoodustamist (Argus 2008b: 19). "Eesti keele käsiraamatu" kohaselt tuleneb eriliselt hellitlev ja õrnutsev tundetoon kahe liite koostarvitusest, neid nimetatakse topeltdeminutiivideks, nt kiisukene jne (EKK 2007: 623).

3. Mittesufiksaalsel teel, s.o häälikuvahelduse ( $i$-hääliku sisestamine tüvesse, nt lipp 'väike lapp'), lühendamise (desufiksatsioon, nt hobu, ja omastavavormi leksikaliseerimine, nt poja) ja geminatsiooni (emm 'emme') abil tuletatud deminutiividega (Kehayov \& Blokland 2006).

4. Laiendosadega väike-, pisi- liitsõnadega, mis lisaks füüsilistele mõõtmetele võivad väljendada ka hinnangut (Kasik 2015: 241-242), nt väikefirma jne.

5. Hinnangulist tähendust väljendavate liitsõnadega, "milles modifitseerijaks on liitsõna põhiosa. Erinevus liitsõna ja selle täiendosa tähenduste vahel on üksnes stiililine: mõistet nimetab laiendosa, modifitseeriv põhiosa lisab sellele afektiivse tähendusvarjundi” (Kasik 2015: 240), nt õeraas, vanamehenäss jne.

\subsection{Deminutiivid tõlketeoorias ja -praktikas}

Tõlketeooriale- ja praktikale ei ole deminutiivide teema sugugi võõras. Juba põgus inglis- või venekeelne otsing internetis annab rohkesti tulemusi erinevate artiklite, diplomi-, magistri- ning doktoritöödena, vt nt Chamonikolasová \& Rambousek 2007; Biały 2015; Golušin 2018; al-Ghazalli 2012; Menkova 2010; Kuusik 2016 jne.

Lisaks deminutiividest tingitud tõlkeraskuste ja -lahenduste analüüsimisele on neid uuritud ka tõlkija soo seisukohast. Mõned tõlkeuurijad on leidnud, et naistõlkijate tööd iseloomustab suurem emotsionaalsus ja ekspressiivsus ning deminutiivsufiksid on üheks oluliseks vahendiks selle saavutamisel, seetõttu on väidetud, et naistõlkijate tekstides on deminutiive märgatavalt rohkem kui meestõlkijate omades (Denissova 2013: 48), käesoleva artikli autori vene-eesti tõlkel põhinev uurimus seda ei tõestanud (vt Kupp-Sazonov 2018) ning ka Tšehhovi jutustuste eestikeelsete tõlgete kõrvutamine käesolevas artiklis ei luba väita, et 
DEMINUTIIVSETE NOOMENITE FUNKTSIONAALSUSEST ...

ainsa naistõlkija (Anna Tuliku) tõlgetes oleks deminutiive rohkem kui tema meeskolleegide tekstides.

Üldiselt on vene-eesti-vene tõlgete seisukohast deminutiividele pööratud suhteliselt vähe tähelepanu. Siiski on mõningates tõlketeemalistes käsitlustes neile möödaminnes osutatud. Näiteks Otto Samma on öelnud, et "tüüpiliseks veaks on vene keeles sagedasti esinevate deminutiivide mehaaniline ülekandmine eesti keelde. Eesti keeles aga kasutatakse deminutiive hoopis vähem, ja originaali mõttenüanssi ei tule mitte alati sel teel edasi anda. Minnakse koguni nii kaugele, et öeldakse "külmake", nagu eesti keeles kunagi ei öelda. Ka ei ole eesti keeles peaaegu üldse tarvitusel "pliiatsike", "viinake" jne., mida tõlkijad aga tarvitavad" (Samma 1954: 352).

Märt Väljataga on deminutiivide tõlkimise küsimuses mõnevõrra teisel arvamusel ning täheldab, et "kunagi hurjutati tõlkijaid, et nad kipuvad alles jätma vene deminutiivide rohkust: "Emake, lehmake kärvas ära!". Teisalt võiks jälle inglise keelest tõlkides julgemini kasutada deminutiive, mis meie keeles on olemas ja neil puuduvad. Originaalkeele grammatika jälgede täielikku kustumist ei tasuks iga hinna eest üritada" (Väljataga 2015: 52).

Ainus põhjalikum deminutiivide tõlkeprobleemidele pühendatud uurimus on Eda Vaigla 1977. aastal ilmud artikkel "Деминутивы эмоциональной окраски в русском и эстонском языках” (Vaigla 1977: 3-41), kus keskendutakse vene-eesti tõlkesuunale. Vaigla mitmed tähelepanekud leiavad kinnitust ka käesoleva artikli tarbeks kogutud materjali analüüsimisel.

Kuna Vaiglat huvitas eelkõige deminutiivide emotsionaalne komponent, siis jäid tema analüüsist kõrvale kõik need näited, kus deminutiividel oli vaid füüsilise väiksuse väljendamise funktsioon, ning samuti ei tehtud vahet deminutiividel, mis väljendavad samaaegselt suurust ja hinnangut, ning neil, millel on puhtalt hinnanguline funktsioon (Vaigla 1977: 6-7), käesolevas artiklis vaadeldakse kõiki neid funktsioone eraldi.

Analüüsides erinevaid teoseid, ei leia Vaigla ühtegi deminutiividega liialdamise juhtumit, pigem esineb deminutiivide "alakasutamist" tõlkes, 
mille tõttu on läinud kaduma lähteteksti nüansid (Vaigla 1977: 14, 17, 18, 34-35). Ka siinses artiklis analüüsitud jutustuste tõlgetes ei esine deminutiivide "ülekasutamist".

\section{Materjal ja metoodika}

Analüüsimaterjaliks on valitud kakskümmend Tšehhovi jutustust ning nende eestikeelset tõlget. Eestindatud tekstid pärinevad kuuelt tunnustatud tõlkijalt: Madis Küla-Nurmik "Kaks lehemeest" (KL); Väino Linask - "Kaebusteraamat" (KR), "Perpetum mobile" (PM), "Album" (A), "Maailmale nähtamatud pisarad" (MNP), "Kohtus" (KOH), "Õnnetus" (Õ), "Hüpik" (H), "Pruut" (PR), "Kodupaigas" (KOD), "Petšeneeg” (PE); Friedebert Tuglas - "Üle soolas" (ÜS), "Inimene vutlaris" (IV), "Palat nr. 6" (PN); Paul Viires - "Apteekri abikaasa" (AA); Anna Tulik - "Must munk" (MM), "Igav lugu" (IL), "Naiste riik" (NR); Enn Murdmaa - "Maja ärklitoaga" (MÄ), "Kirjanduse õpetaja” (KÕ). Seega võib eeldada, et saadud ülevaade deminutiivide kasutamisest ning funktsioneerimisest tõlkes on objektiivsem, kuna see ei põhine vaid ühe tõlkija eelistustel ja otsustel.

Koostatud näidete korpus sisaldab 250 kirjet. Esmalt koondati kõik venekeelsed deminutiivid (sh ka erinevates tekstides korduvalt esinevad sõnad, kuna küllaltki sageli tuleb ette olukorda, kus samal vormil on erinevates kontekstides erinev funktsioon (vt (13a) ja (14a)) ning seejärel täiendati korpust eestikeelsete tõlkevastetega, mis mõningatel juhtudel sisaldasid samuti deminutiivi või deminutiivsuse funktsiooni täitvat keelendit, kuid mitte alati. Tõenäoliselt peitub põhjus selles, et kui jätta kõrvale laste- ja hoidjakeel, siis kasutatakse deminutiive eesti keeles küllaltki tagasihoidlikult, seda on muuhulgas põhjendatud "eestlase üldiselt kaine väljenduslaadiga" (Vare 1994: 12).

Korpuses on esindatud ka need näited, kus tõlkes on deminutiivi puudumisel selle funktsioon omistatud adjektiivile või hinnangulise semantikaga liitsõnale. Sõna määratlemisel deminutiivina tugines artikli autor oma keelevaistule ja kontrollis oma seisukohta ka "Eesti keele seletavast sõnaraamatust" (EKSS 2009) ning mitme vene keele seletava 
sõnaraamatu (nt Efremova 2000; Kuznetsov 2014; Ušakov 2008) veebiversioonidest.

\section{Deminutiivide funktsioonid Tšehhovi jutustustes ja nende eestikeelsetes tõlgetes}

Uurimismaterjalis leidub näiteid eelpool mainitud traditsioonilise deminutiivide funktsioonide klassifikatsiooni iga punkti kohta, kuid tõlkelahendused on sama funktsiooni täitvate deminutiivide puhul väga erinevad. Analüüsi käigus proovitakse välja selgitada, kas ja kuidas on tõlkijad üritanud sihttekstis säilitada lähtekeele deminutiivi funktsiooni.

Korpuse 250 vene keele deminutiivist 120 vastena ei ole tõlkijad eesti keeles deminutiive kasutanud ega üritanud ka neid kuidagi kompenseerida, 106 juhul on tõlkevasteks deminutiiv ning 24 korral võib rääkida kompenseerimisest.

\subsection{Suurus + hinnang}

Mõnevõrra üllatav on asjaolu, et vaadeldud jutustustes on suhteliselt vähe elusolendeid tähistavaid deminutiive, mis väljendaksid samaaegselt vähendavat ja hellitavat suhtumist. See funktsioon säilitatakse ka tõlkes deminutiivide abil:

(3a) канареечки мои (NR)

(3b) minu linnukesed

(4a) серый петушок (PE)

(4b) hall kukeke

Rohkesti leidub elusolendite kehaosi tähistavaid deminutiive, mis reeglina säilitatakse ka tõlkes (5b), (6b) ja (7b). Aga esineb ka erandeid, nt (8b), kus tegelikult võiks kasutada sõna näokeses, ja kompenseerimist (9b), mille asemel oleks mõeldav variant vurrukesed.

(5a) Один пальчик назывался у нее фисташковым (IL)

(5b) Üht oma sõrmekest hüüdis ta pistaatsiasõrmeks 
(6a) ротик полуоткрыт [---] и ножка с кровати свесилась (АА)

(6b) suuke poollahti [---] jalake rippumas üle voodi ääre

(7a) Глазенки так и стреляют! (АА)

(7b) Silmakesed aina tulistavad.

(8a) светилась на ее личике (IL)

(8b) ta näos säras

(9a) с нафабренными усиками (IL)

(9b) pisikesed võitud vurrud

Sarnast mitmekesisust tõlkevastete osas näeme ka elutute objektidega. Esineb deminutiiviga tõlkevasteid (10b), samuti kompenseerimist adjektiiviga (11b), aga tuleb ette ka deminutiivsuse ignoreerimist (12b).

(10a) в шапочке (IL)

(10b) mütsike peas

(11a) у вас миленькая аптечка! (AА)

(11b) teil on väga armas väike apteek!

(12a) очень веселенькой комнатке с голубыми обоями (IL)

(12b) väga rõõmsasse, helesiniste tapeetidega tuppa

Suuruse + hinnangu tähenduse puhul ei saa jätta veel kord toonitamata konkreetset konnotatsiooni toetava konteksti rolli. Jutustuses "Kirjanduse õpetaja" omandab üks ja sama sõnapaar гориочки со сметаной erinevates kontekstides täiesti vastupidise semantika. Ühel juhul mõtleb vastabiellunud mees õrnusega oma noore kaasa esimestele sammudele perenaise elus (13a) ja (13b) ning mõnevõrra hiljem on ta pettunud oma abielus, abikaasas, kuna see kõik näib talle tühine ning tähtsusetu (14a) ja (14b).

(13a) у нее в погребе и на погребице было много кувшинов с молоком и горшочков со сметаной (КО̃)

(13b) tal oli keldris ja keldripealses ruumis hulk savikannusid piimaga ning potte hapukoorega

(14a) Скучные, ничтожные люди, горшочки со сметаной, кувшины с молоком, тараканы, глупые женщины (КО̃)

(14b) Igavad inimesed, tühised inimesed, potikesed hapukoorega, savikannud piimaga, tarakanid, rumalad naised 
DEMINUTIIVSETE NOOMENITE FUNKTSIONAALSUSEST ...

Eestikeelses tõlkes esineb deminutiiv vaid ühel juhul (14b) ning selle eesmärgiks on näidata tegelase halvustavat suhtumist. Näib, et tõlkija oleks võinud deminutiivi kasutada ka esimesel korral (st positiivse hinnangu tarbeks), kuna sel juhul oleks paremini säilinud originaaltekstis nähtav tegelase koomilisus, kes oma rahulolu abieluga või pettumust selles väljendab muuhulgas ka majapidamisnõudega.

Ka üheaegselt vähendavate ja halvustavate deminutiivide edasiandmisel eesti keeles ei saa välja tuua ühte kindlat tõlkestrateegiat. Esineb nii ignoreerimist (15b) kui ka kompenseerimist (16b) ja (17b).

(15a) маленький, тщедушный солдатик с ружьем $(\mathrm{KOH})$

(15b) väike kõhetu soldat püssiga

(16a) идти лекарем в грязный, глупый городишко (PN)

(16b) minna tohterdajaks räpasese rumalasse linnaräbalasse

(17a) маленькая облезлая собачонка (КО̃)

(17b) väike luitunud koeranäss

Näitelause (15a) laiema konteksti põhjal jääb mulje, et lähteteksti deminutiiviga väljendab autor haletsust sõduri suhtes, kuna tegu on saamatu isikuga, kes komistab ja pillab püssi käest ning kõige selle tulemusena punastab suurest häbist. Eestikeelne vaste soldat päris sama funktsiooni ei täida, kaaluda võiks varianti soldati-/sõdurihakatis, millega saaks ka sihtkeeles toonitada isiku kohmakust ja ebakompetentsust. Kompenseerimisvõtteid lausetes (16b) ja (17b) võib pidada igati õnnestunuteks, sõnad linnaräbal ja koeranäss väljendavad halvustavat suhtumist kindlasti paremini kui sõnad linnake ja koerake seda teeksid, isegi toetavate adjektiividega.

\subsection{Hinnang}

Hellitava tähenduse puhul on selges ülekaalus elusolendeid tähistavad deminutiivid, mis enamjaolt säilivad ka tõlkes, nt (18b), (19b), (20b) ja (21b). Nendel juhtudel, kui deminutiivi tõlkevastena ei kasutata, näib põhjus peituvat konkreetse lekseemi semantikas, näiteks võib tõlkijal tekkida tõrge tuletada deminutiiv sõnast lesk (18b). 
(18а) Я всё про барыньку думаю, про вдовушку, (РМ)

(18b) Ma mõtlen ikka sellele prouakesele, sellele lesele

(19a) Дай, ангелочек, ключи (MNP)

(19b) Anna, inglike, võtmed

(20а) на хуторе живет мамочка (IV)

(20b) talus elab emake

(21a) - Здравствуй, папочка. (IL)

(21b) “Tere, papake."

Esiletoomist väärib juhtum, mis on analüüsitud materjalis ainulaadne, kuna deminutiiv esineb vaid tõlkes. Jutustuses "Kirjanduse õpetaja" soovib peategelane kirjutada oma armsamale ning tahab alustada kirja sõnadega милая моя крыса ('mu armas rott'), nähtavasti pole selles pöördumises tõlkija jaoks piisavalt õrnust, seepärast on tõlkes variant minu armas rotike.

Elututesse objektidesse suhtutakse hellitavalt (ilma viiteta objekti väiksusele) nendest jutustustes väga vähe, leida õnnestus üks näide, mis on tõlkes lahendatud adjektiivi lisamisega (22b).

(22a) курю трубочку. (IL)

(22b) suitsetasin oma armsat piipu.

Halvustavat suhtumist väljendavaid deminutiive kasutatakse nii elusolendite kui ka objektide tähistamiseks. Tõlkimisstrateegiad on erinevad, elusolendite puhul säilivad deminutiivid ka tõlkes (23b), (24b) ja (25b), elutute objektide puhul on deminutiivide kasutamine tõlkevastetena harvem nähtus.

(23a) развратный мальчишка (О̃)

(23b) kõlvatu poisike

(24a) Водевильные дядюшки (MМ)

(24b) Koomilised, rahuloleva ja lihtsameelse näolapiga onukesed

(25a) Хоть и дрянной человечишка, но гостеприимен (PM)

(25b) On küll muidu räbal mehike, aga külalislahke

Jutustuses "Maja ärklitoaga" osaleb minategelane vaidluses, kus tema vestluskaaslane nimetab talurahva elu parandamiseks vajalike meetmete 
seas haridust (sh raamatuid ja raamatukogusid) ja arstiabi (apteeke ja haiglaid). Minategelane on aga arvamusel, et kõik see hoopis halvendaks talupoegade olukorda veelgi. Oma põlgust väljapakutud meetmete suhtes väljendab ta kasutades deminutiive аптечки (neli korda), книжки (neli korda) ja библиотечки (kolm korda). Jääb mulje, et tõlkija ei ole päriselt mõistnud deminutiivide funktsiooni selles kontekstis, kuna tõlkes esineb vaid üks kord sõna raamatukesed ja üks kord raamatukogukesed, ka ei ole üritatud tegelase halvustavat suhtumist nendesse objektidesse mingisuguste teiste keelenditega kompenseerida.

(26а) По-моему, медицинские пункты, школы, библиотечки, аптечки, при существующих условиях, служат только порабощению.

(26b) Minu arvates arstiabipunktid, koolid, raamatukogud ja apteegid olemasolevate tingimuste juures ainult soodustavad orjastamist.

\subsection{Suurus}

Vaigla jõudis järeldusele, et vastupidiselt vene keelele ei väljendata eesti keeles füüsilist väiksust reeglina deminutiiviga (Vaigla 1977: 6). Tšehhovi jutustuste tõlgete analüüs näib seda väidet kinnitavat, kuna suurem osa neist 120 juhtumist, kus tõlkevasteks ei ole deminutiiv ega ka mõni selle funktsiooni kompenseeriv keelend, puudutab just mõõtudelt väikseid elutuid objekte, nt (27b), (28b) ja (29b).

(27a) любовно поглядывал на потолок, где торчал крючок (KL)

(27b) vaatas armunud pilgul lakke, kus paistis konks

(28a) Сейчас за лесом, только мостик переехать. (РМ)

(28b) Kohe metsa taga, ainult üle silla sõita.

(29a) кусочки хлеба, бумажки и косточки (PN)

(29b) leivatükke, pabereid ja konte

Põhjuseid originaaltekstide deminutiivide ignoreerimiseks võib olla mitmeid. Mõnel juhul (nt konks, leivatükid, kondid) võib näida nende objektide füüsiliste mõõtmete rõhutamine eesti keeles üleliigsena, kuna on teada, et need on väikesed objektid. Mis puudutab lauset (28b), siis 
ehk siin on põhjus vastupidine - tõlkija seisukohast ei tundu loogiline kasutada deminutiivi silla kohta, millest saab hobuse ja vankriga üle sõita, kaaluda võiks muidugi kompenseerimist adjektiiviga nagu lauses (30b). Samas sõnast maja tuletatakse deminutiiv rohkem kui korra (31b).

(30а) Вот бакалейная лавочка (IL)

(30b) Siis möödun väikesest koloniaalkauplusest

(31a) маленький домик (IL)

(31b) väike majake

Erinevaid tõlkelahendusi pakub venekeelne sõna минутка 'minutike,' mida võib tõlgendada minutist lühema ajaperioodina. Just sellest loogikast on lähtunud ka eesti tõlkijad, valides vasteteks nt hetk ja viiv (IL) ning silmapilk (PR).

Millegi väiksemat intensiivsust väljendavaid deminutiive leidub nendes jutustustes samuti rohkesti, enamasti koos vastavate adjektiividega. Ühest tõlkelahendust pole võimalik esile tuua, leidub nii tõlkimist deminutiiviga (32b) kui ka ilma selleta (33b) ja (34b). Näite (33b) kohta tuleb mainida, et olemasolev tõlkevariant pole sugugi ainuvõimalik, sõna naeratus oleks mõeldav asendada sõnaga muie (mille tähendus EKSS-i kohaselt on 'kerge põgus naeratus'). Lekseemi hääl puhul on deminutiivi vältimine pigem tervitatav, nii ei teki eesti keelele mitteomast deminutiivide üleküllust, sest adjektiiv peenike on juba deminutiiv.

(32a) легкий вечерний ветерок (MM)

(32b) kerge õhtune tuuleke

(33a) говорил он мне со слабой кривой улыбочкой (IV)

(33b) rääkis ta minule nõrga virila naeratusega

(34a) сказала она робко, тонким голоском (H)

(34b) ütles Olga Ivanova arglikult, peenikesel häälel

Väiksema tähtsuse funktsiooni võivad Tšehhovil täita nii elusolendeid (35a), objekte (36a) kui ka abstraktseid nähtusi (37a) tähistavad lekseemid. Tõlkelahendused on jällegi erinevad, lauses (35b) on lisatud laiendosa pisi-, näites (36b) pole kasutatud sõna artiklid, mis võiksid viidata 
DEMINUTIIVSETE NOOMENITE FUNKTSIONAALSUSEST ...

tõsistele ja põhjalikele teadustekstidele, vaid räägitakse kirjutistest ning näites (37b) on valitud liitsõna, mille üks osa on deminutiiv. Seega võib väita, et kõikidel nendel juhtudel on deminutiivide funktsiooni õnnestunud edasi anda ka tõlgetes.

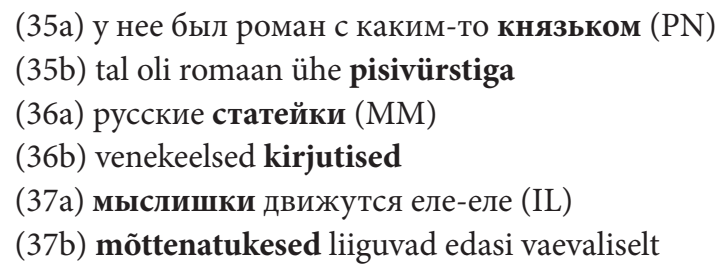

\subsection{Viisakus}

Analüüsitud materjalis esines vene keelele omast deminutiividega viisakuse ja aupaklikkuse väljendamise funktsiooni korduvalt söögi-joogi puhul, kui vestluskaaslasele räägiti pakutavatest hõrgutistest, nt (38a). Tõlgetes nendel juhtudel deminutiive ei ole, ainsaks erandiks on anumad joodava jaoks (klaasid, pudelid), nt (39b) ja (40b). Ka elusolendite tõlkevastetes ei esine deminutiive, kuid tuleb ette kompenseerimist adjektiiviga (41b).

\footnotetext{
(38а) Огурчика, колбаски [---] самоварчик изобразим (MNP)

(38b) Kurki, vorsti [---] paneme teemasina susisema

(39а) Выпьем по рюмочке (MNP)

(39b) Rüüpame klaasikese

(40а) Сочините-ка нам бутылочки три! (АА)

(40b) Võluge meile õige pudelikest kolm!

(41a) Ваш батюшка и дядюшка (NR)

(41b) Teie armas isa ja onu
}

\section{Kokkuvõtteks}

Artiklis kõrvutati ja analüüsiti deminutiivide funktsionaalsust kahekümnes Tšehhovi jutustuses ning nende eestikeelsetes tõlgetes. Aluseks võeti vene keele grammatika traditsiooniline deminutiivide funktsioonide 
liigitus, mille järgi grupeeriti ka lähtetekstidest leitud deminutiivid. Seejärel kõrvutati neid tõlgetega ning üritati tuvastada, kas ja kuidas on deminutiivi funktsiooni säilitatud sihttekstis. Vastava funktsiooni täitmiseks loeti nii deminutiivi kasutamist tõlketekstis kui ka selle kompenseerimist teiste keeleliste vahenditega (nt adjektiividega, hinnaguliste liitsõnadega jms). Analüüsi tulemused lubavad teha järgmisi järeldusi.

1. Suuruse + hinnagu väljendamise funktsiooni pidasid tõlkijad oluliseks säilitada, kasutades selleks deminutiive (5b), (6b); hinnangulisi liitsõnu (16b), (17b); kompenseerimist adjektiividega (9b), (11b).

2. Hinnangulise funktsiooni korral on valitud tõlkestrateegia lahutamatult seotud sellega, kas deminutiiv tähistab elusolendit või elutut objekti. Esimesel juhul deminutiivid säilitatakse, sõltumata konkreetsest hinnangust (20b), (21b), (24b), (25b). Elutute objektide puhul jääb hinnangu väljendamine pigem terve konteksti ülesandeks ning deminutiive kasutatakse oluliselt vähem.

3. Suuruse väljendamise funktsiooni puhul leidis üldiselt kinnitust Vaigla seisukoht, et füüsilist väiksust ei väljendata eesti keeles reeglina deminutiividega, ka käesoleva artikli näidete korpusest võib selliseid juhtumeid leida vaid üksikuid, nt (31b). Veidi teistsugune on olukord siis, kui deminutiivi funktsiooniks on edasi anda väiksemat intensiivsust või tähtsusetust, nendel juhtudel esineb ka tõlkes sagedamini deminutiive (32b) või nende funktsiooni kompenseerimist muude vahenditega (35b), (37b).

5. Viisakuse ja aupaklikkuse funktsiooni puhul on Vaigla oma artiklis küllaltki kategooriline ja väidab, et selle tähenduse väljendamine deminutiividega pole eesti keelele omane (Vaigla 1977: 19) ning tema analüüsitud tõlgetes selliseid juhtumeid ka ei esinenud. Tšehhovi eestindustes tuli seda siiski ette, nt kui viidati joodavale (39b), (40b) ning elusolendite tõlkevastetes esines kompenseerimist (41b), kuid võib julgelt väita, et tegu on tõepoolest üksikute juhtumitega.

250 analüüsitud näite põhjal võib järeldada, et tõlkijad suhtuvad küllaltki tähelepanelikult originaaltekstides esinevate deminutiivide funktsioonidesse ning üritavad neid võimalusel ka tõlgetes säilitada. 
DEMINUTIIVSETE NOOMENITE FUNKTSIONAALSUSEST ...

Kui puudub võimalus kasutada deminutiivi, siis püütakse seda vähemalt kompenseerida teiste keelenditega. Põhjus, miks siiski pea pooltel juhtudel (120 näites) puuduvad sihttekstis nii deminutiivid kui ka kompenseerivad vahendid, peitub nähtavasti eesti keele "deminutiivileiguses" ning ka selles, et tõlkijad on sunnitud otsima habrast tasakaalu selle vahel, et üritada anda edasi vene inimese mõttemaailmale omast loogikat ning samal ajal säilitada tõlkes ilus ja loomulik eesti keel.

\section{Materjali allikad}

Tšehhov, Anton 2005. Jutustused. Tallinn: Tänapäev.

Национальный корпус русскго языка. http://ruscorpora.ru/index.html (12.2.2019).

Чехов, Антон 1975. Полное собрание сочинений и писем в тридцати томах. Сочинения: в восемнадцати томах. Том 3. Москва: Наука.

Чехов, Антон 1976. Полное собрание сочинений и писем в тридцати томах. Сочинения: в восемнадцати томах. Том 5. Москва: Наука.

Чехов, Антон 1983. Полное собрание сочинений и писем в тридцати томах. Том 2. Москва: Наука.

Чехов, Антон 1984. Полное собрание сочинений и писем в тридцати томах. Том 4. Москва: Наука.

Чехов, Антон 1985. Полное собрание сочинений и писем в тридцати томах. Том 7. Москва: Наука.

Чехов, Антон 1985. Полное собрание сочинений и писем в тридцати томах. Сочинения: в восемнадцати томах. Том 8. Москва: Наука.

Чехов, Антон 1986. Полное собрание сочинений и писем в тридцати томах. Том 9. Москва: Наука.

\section{Kirjandus}

al-Ghazalli, Mehdi F. 2012. Diminutives in Arabic-to-English translation. - Babel 58 (4), 395-407.

Argus, Reili 2008a. Eesti keele muutemorfoloogia omandamine ['Acquisition of Estonian Morphology']. Tallinna Ülikooli humanitaarteaduste dissertatsioonid 19. Tallinn: Tallinna Ülikooli Kirjastus.

Argus, Reili 2008b. Kuidas eesti laps vormimoodustuse omandab ['Acquisition of Estonian morphology']. - Oma Keel 1, 16-26. 
Azarova 2011 = Лариса Азарова. Язык произведений А. П. Чехова ['The language of the works by A. Chekhov']. - Вестник Таганрогского института имени А. П. Чехова. Вып. 1. Таганрог, 83-86.

Bagasheva-Koleva, Mariya 2016. On the category of diminutiveness in English, Russian and Bulgarian. - International Scientific and Practical Conference "WORLD SCIENCE" 2 (6), 4, 7-10. http://archive.ws-conference.com/ wp-content/uploads/284.pdf (12.2.2019).

Biały, Paulina 2015. Polish and English diminutives in Literary Translation: Pragmatic and Cross-Cultural Perspectives. Praca doktorska. Katowice: Uniwersytet Śląski.

Bosanac, Siniša, Dora Lukin, Petra Mikolić 2009. A Cognitive Approach to the Study of Diminutives: The Semantic Background of Croatian Diminutives. Zagreb.

Bratus, Boris 1969. The Formation and Expressive Use of Diminutives. Studies in the Modern Russian Language 6. Cambridge: Cambridge University Press.

Böhmerová, Ada 2011. Suffixal diminutives and augmentatives in Slovak: A systemic view with some cross-linguistic considerations. - Lexis 6: Diminutives and Augmentatives in the Languages of the World. http://lexis.univ-lyon3. fr/IMG/pdf/Lexis_6.pdf (12.2.2019).

Chamonikolasová, Jana, Jiří Rambousek 2007. Diminutive expressions in translation: A comparative study of English and Czech. - Belgian Journal of Linguistics 21 (1), 37-52.

Denissova 2013 = Ирина Денисова. Отражение гендерной принадлежности переводчика при переводе художественного произведения ['Reflection of the translator's gender in translation']. - Вестник Челябинского государственного университета. Серия “Филология. Искусствоведение”. Челябинск: Челябинский государственный университет, 48-51.

Dressler, Wolfgang, Merlini Barbaresi 1994. Morphopragmatics: Diminutives and Intensifiers in Italian, German, and Other Languages. Berlin: Mouton de Gruyter.

Efremova 2000 = Татьяна Ефремова. Новый словарь русского языка. Толковословообразовательный ['New explanatory derivation Russian dictionary']. Москва: Русский язык. https://www.efremova.info/ (12.2.2019).

EKG 1995 = Mati Erelt, Reet Kasik, Helle Metslang, Henno Rajandi, Kristiina Ross, Henn Saari, Kaja Tael, Silvi Vare. Eesti keele grammatika I. Morfoloogia. Sõnamoodustus ['The grammar of the Estonian language I: Morphology. Word-formation']. Eesti Teaduste Akadeemia Eesti Keele Instituut. Tallinn. 
DEMINUTIIVSETE NOOMENITE FUnKTSIONAALSUSEST ...

EKK 2007 = Mati Erelt, Tiiu Erelt, Kristiina Ross. Eesti keele käsiraamat ['The handbook of Estonian']. Tallinn: Eesti Keele Sihtasutus.

EKSS 2009 = Margit Langemets, Mai Tiits, Tiia Valdre, Leidi Veskis, Ülle Viks, Piret Voll. Eesti keele seletav sõnaraamat 1-6 ['Explanatory dictionary of Estonian']. Tallinn: Eesti Keele Sihtasutus.

Fufajeva 2017 = Ирина Фуфаева. Экспрессивные диминутивы в условиях конкуренции с нейтральными существительными (на материале русского языка) ['Expressive diminutives in competition with neutral nouns (on the material of the Russian language)']. Диссертации на соискание ученой степени кандидата наук по научной специальности. Москва: РГГУ. http://www2.rsuh.ru/binary/object_25.1524220762.60183. PDF (12.2.2019).

Gadžijeva 2014 = Нинель Гаджиева. Особенности языка произведений А. П. Чехова ['Language features of the works by Anton Chekhov']. Социосфера 54 (4). Наука, 54-57.

Galkina-Fedoruk 1960 = Евдокия Галкина-Федорук. О языке А. П. Чехова ['A. Chekhov's Language']. - РЯШ 1, 2-9.

Golušin 2018 = Иван Голушин. Диминутив как носитель эмотивного значения: проблема перевода ['Diminutive emotive meaning as a translation problem']. - Вестник Череповецкого государственного университета 83 (2), 70-76.

Jurafsky, Daniel 1996. Universal tendencies in the semantics of the diminutive. Language 72 (3), 533-578.

Kasik, Reet 2004. Eesti keele sõnatuletus ['Derivation in Estonian']. Tartu: Tartu Ülikooli Kirjastus.

Kasik, Reet 2009. Eesti keele sõnatuletus ['Derivation in Estonian']. Tartu: Tartu Ülikooli Kirjastus.

Kasik, Reet 2015. Sõnamoodustus ['Word-formation']. Eesti keele varamu 1. Tartu: Tartu Ülikooli Kirjastus.

Kehayov, Petar, Rogier Blokland 2006. Mittesufiksaalne deminutiivituletus eesti keeles ['Non-suffixal diminutive derivation in Estonian']. - Emakeele Seltsi aastaraamat 52, 87-124.

Kerge, Krista 1991. Morfopragmaatilised seigad eesti tuletuses ['Morphopragmatic matters in Estonian derivation']. - Jaan Õispuu, Krista Kerge (Toim.). Eesti keele ja kirjanduse kateedri töid II. Tallinn: Tallinna Pedagoogiline Instituut, 26-29. 
Kozlovskaja 1992 = Татьяна Козловская. Хочу сказать о языке сахарном, сладеньком, сусальном ['I want to tell about the language of sugar, sweet, sugar-sweet']. - Русская речь 3, 55-57.

Koževnikova 2011 = Наталья Кожевникова. Стиль Чехова ['The style of Chekhov']. Москва: Издательский центр.

Kupp-Sazonov, Sirje 2013. Grammatiline sugu - tõlkija sõber või vaenlane? ['Grammatical gender - translator's friend or enemy?']. - Paar sammukest. XXVIII Eesti Kirjandusmuuseumi aastaraamat 2011. Tartu: Eesti Kirjandusmuuseumi Teaduskirjastus, 103-126.

Kupp-Sazonov, Sirje 2018. Kas mehed ja naised tõlgivad tõepoolest erinevalt? Aleksei Tolstoi jutustuse "Kuldvõtmeke ehk Buratino seiklused" nelja eestinduse näitel ['Do women and men really translate differently? Four Estonian translations of A. Tolstoy's story “The Golden Key, or the Adventures of Buratino"']. - Keel ja Kirjandus 6, 453-471.

Kuzmenkova 2007 = Валентина Кузьменкова. Диминутив как средство выражения имплицитных смыслов высказывания ['Diminutive as a means of expressing the implicit meanings of a statement']. - В. В. Кpacных, А. И. Изотов (Ред.). Язык, сознание, коммуникация. Вып. 34. Москва, 38-45.

Kuznetsov 2014 = Сергей Кузнецов. Большой толковый словарь русского языка ['Great explanatory dictionary of the Russian language']. http://gramota.ru/slovari/info/bts/ (12.2.2019).

Kuusik, Katre 2016. Los diminutivos en español y la traducción de ellos al estonio. Tesina de grado. ['Diminutives in Spanish and their translation into Estonian']. BA theses. University of Tartu. http://hdl.handle.net/10062/51917 (12.2.2019).

Lockyer, Dorota 2012. Such a tiny little thing: Diminutive meanings in Alice in Wonderland as a comparative translation study of English, Polish, Russian and Czech - Verges: Germanic \& Slavic Studies in Review 1 (1), 10-23.

Menkova 2010 = Нелли Менькова. Русские диминутивы в английском переводе романа М. А. Булгакова “Мастер и Маргарита” ['The Russian diminutives in English translation of the novel by M. A. Bulgakov "The Master and Margarita”']. - Ярославский педагогический вестник 1 (3). Ярославль, 174-179.

Menkova 2014 = Нелли Менькова. Диминутивная форма как способ обозначения пола лица ['A diminutive form as a way to denote the person's gender']. - Ярославский педагогический вестник 1 (1). Ярославль, 93-98. 
DEMINUTIIVSETE NOOMENITE FUNKTSIONAALSUSEST ...

Mintsys, Ella, Yuliya Mintsys 2015. Theoretical principles of researching diminutive. - Journal of Vasyl Stefanyk Precarpathian National University 2 (2-3), 29-35. http://dx.doi.org/10.15330/jpnu.2.2-3.29-35

Mägiste, Julius 1928. oi-, ei-deminutiivid läänemeresoome keeltes. Läänemeresoome nominaaltuletus I ['oi-, ei-diminutives in the Balto-Finnic languages']. Acta et Comentationes Universitatis Tartuensis B 12/2. Tartu: [Tartu Ülikool].

Mägiste, Julius 1929. Eesti -ss-aineselisest deminutiivsuffiksist ['Estonian -ss-diminutive suffix']. - Eesti Keel 3-4, 69-75.

Orusalu, Silja 1996. Lastega suhtlemise erisõnavara ['Special vocabulary of Estonian child adjusted speech']. Diplomitöö käsikiri Tartu Ülikooli eesti keele õppetoolis.

Pajusalu, Renate, Virve Vihman, Birute Klaas, Karl Pajusalu 2010. Eestlaste ja venelaste suhtluskäitumine: sina, teie ja keegi veel ['Politeness behavior among Estonians and Russians: Formal and informal second person and the third person']. - Eesti Rakenduslingvistika Ühingu aastaraamat 6, 207224. https://dx.doi.org/10.5128/ERYa6.13

Protassova 2001 = Екатерина Протасова. Роль диминутивов в современном русском языке ['The role of diminutives in Modern Russian']. - Труды по русской и славянской филологии. Лингвистика. Tartu, 72-88.

Rezanova 1996 = Зоя Резанова. Функциональный аспект словообразования: Русское производное имя ['Functional aspect of word formation: Russian derivative noun']. Томск: Издательство Томского университета.

Samma, Otto 1954. Tüüpilistest puudustest ja vigadest proosa tõlkimisel vene keelest eesti keelde ['Typical shortcomings and mistakes in translating prose from Russian into Estonian']. - Looming 3, 348-358.

Schneider, Klaus 2003. Diminutives in English. Max Niemeyer Verlag Gmbh.

Spiridonova 1999 = Нина Спиридонова. Русские диминутивы: проблемы образования и значения ['Russian diminutives: Problems of formation and semantics']. - Известия АН. Серия литературы и языка 58 (2), $13-22$.

Šeidajeva 1998 = Светлана Шейдаева. Категория субъективной оценки в русском языке ['The category of subjective assessment in Russian']. Нижний Новгород. Ижевск. http://cheloveknauka.com/v/554211/a?\#?page=1 (12.2.2019).

Zemskaja 1981 = Елена Земская. Русская разговорная речь. Словообразование. Синтаксис ['Russian spoken language. Word formation. Syntax']. Москва. 
Toomejõe, Heidi 2008. Hinnanguline sõnavara noortekeeles ['Expressive vocabulary in the youth language']. - Akadeemiake: õpilaste teadusajakiri, 35-60.

Tšervenkova 1961 = Ирина Червенкова. О лексикализации уменьшительных существительных в современном русском языке ['On the lexicalization of diminutive nouns in Modern Russian']. - Научные доклады высшей школы. Филологические науки 2, 49-59.

Tšervenkova 1965 = Ирина Червенкова. К вопросу об уменьшительных существительных в русском языке ['On the diminutive nouns in Russian']. - Научные доклады высшей школы. Филологические науки 1, $140-151$.

Ušakov 2008 = Дмитрий Ушаков. Большой толковый словарь современного русского языка ['Great explanatory dictionary of the Modern Russian language']. https://ushakovdictionary.ru/ (12.2.2019).

Vaffa 2013 = Эльвия Ваффа. Особенности диминутивных образований в ранних рассказах А. П. Чехова ['Features of diminutive formations in the early stories by A. Chekhov']. Воронеж: Воронежский государственный университет.

Vaffa \& Kovaljov 2013 = Эльвия Ваффа, Геннадий Ковалев. Обозначение людей диминутивной лексикой в ранних рассказах А. П. Чехова ['Designation of people by diminutive vocabulary in the early stories by A. Chekhov']. - Вестник Воронежского государственного университета. Филология и журналистика 2, 116-119.

Vaigla 1977 = Эда Вайгла. Деминутивы эмоциональной окраски в русском и эстонском языках ['Emotional diminutives in Russian and Estonian']. Ученые записки Тартуского государственного университета. Труды по русской и славянской филологии XXVII. Серия лингвистическая. Тарту, 3-41.

Vainik, Ene 2012. Eesti keele sõnavara afektikalduvus ja mis sellega peale hakata ['Bias of affect in Estonian lexis and what to do with it']. - Keel ja Kirjandus 8-9, 644-657.

Vare, Silvi 1981. Nimisõnaliited tänapäeva eesti kirjakeeles ['Noun suffixes in Modern Estonian']. Tallinn: Valgus.

Vare, Silvi 1994. Nimi- ja omadussõnatuletus tänapäeva eesti kirjakeeles ['Derivation of nouns and adjectives in Modern Estonian']. Dissertationes philologiae estonicae Universitatis Tartuensis 6. Tartu: Tartu Ülikooli Kirjastus.

VKAG I 1980 = Русская грамматика 1 ['Russian grammar']. Н. Ю. Шведова (Гл. ред.). Москва: Наука. 
Väljataga, Märt 2015. Tõlkida värssi ['On the translation of verse']. - Tõlkija hääl. Eesti Kirjanike Liidu tõlkijate sektsiooni aastaraamat. Tallinn, 47-63.

Wierzbicka, Anna 1984. Diminutives and depreciatives: semantic representation for derivational categories. - Quaderni di Semantica 5 (1), 123-130.

Wierzbicka, Anna 1992. Personal Names and Expressive Derivation - Semantics, Culture, and Cognition: Universal Human Concepts in Culture-Specific Configurations. New York: Oxford University Press, Inc.

Õim, Asta 2003. Kuidas vanasti lapsi hellitati ['How they used to pamper children']. - Oma Keel 1, 38-41.

\section{Sirje Kupp-Sazonov}

Tartu Ülikooli maailma keelte ja kultuuride kolledž

Lossi 3, 51003 Tartu, Estonia

sirje.kupp-sazonov@ut.ee 


\title{
On the functionality of diminutive nouns in Russian and Estonian using some A. Chekhov stories and their Estonian translations as examples
}

\author{
SIRJE KUPP-SAZONOV \\ University of Tartu
}

This study focuses on the use of diminutives in Russian and Estonian. The current paper has three main aims: 1) to analyse the functions of diminutive nouns in twenty A. Chekhov stories; 2) to examine if these functions are preserved in the Estonian translations of these stories; 3 ) to identify if and how translators compensate for missing diminutives in Estonian texts.

The two languages under comparison have significant differences in the formation and use of diminutives. Namely, the Russian language provides a large number of suffixes for the derivation of diminutives and diminutives can be derived from nouns, adjectives, adverbs and even interjections. In contrast, in Estonian there are fewer means for deriving diminutives (e.g., derivatives $-k e$, -kene and $-u$ for nouns; -ldane, -jas and -kas for adjectives and some other forms).

Furthermore, the use of diminutives also differs significantly between Russian and Estonian. Russian allows the derivation of diminutives from almost any word (living creatures, objects and even phenomena such as rain or snow, etc.). In Estonian it is natural to form diminutives from nouns referring to people or animals, but it is much less common to derive diminutives from objects, and very rarely does this happen with nouns for natural phenomena.

Analysis of original Russian texts and their Estonian translations shows that diminutives can express a wide spectrum of different meanings. Based on the 250 examples under analysis, it can be concluded that translators are fairly attentive to the functions of diminutives in original texts and they try to preserve them in translations if at all possible. If there is no way to use a diminutive form in Estonian translators at least try to compensate for it by other means.

Keywords: contrastive grammar; diminutives; translation; Russian; Estonian 